\title{
Food Regimes Revisited: A New Zealand Perspective
}

\author{
Michael Roche
}

Michael Roche, School of People Environment and Planning, Massey University, Palmerston North, New Zealand (M.M.Roche@massey.ac.nz)

\begin{abstract}
'Food Regimes' was coined by Friedmann and McMichael in 1989 and provided a organising framework for a considerable amount of Australian and New Zealand research during a period of economic restructuring and 'deregulation'. Subsequently Food regimes were overtaken by other perspectives in New Zealand and elsewhere including an interest in commodity productions chains, regulation, postproductivist landscapes, and post structural political economy. More recently McMichael has reintroduced Food Regimes to his analysis. The paper will compare and contrast McMichael's earlier and more recent engagements with Food Regimes. The export meat, the dairy, and pip fruit industries of Zealand it will be used to illustrate points about the timing, boundaries and margins as well as the transformation of Food Regimes. Finally the paper will attempt to connect the more recent focus on commodity chain analysis and post productivist landscapes with McMichael's renewed interest in food Regimes.
\end{abstract}

Keywords: food regimes, New Zealand, agri-food systems

\section{Introduction}

For New Zealand (NZ) agricultural and economic geographers 'Food Regimes' (Friedmann and McMichael, 1989) provided a meso-level concept of particular significance during a period of economic restructuring and 'deregulation' (Le Heron, 1993, 2002; Le Heron and Roche 1996; McKenna et al. 1998; Roche, 1999). Internationally Food Regimes soon attracted interest and then criticisms before fading from the geographical arena as attention passed to actor network theory, commodity chains, post-productivism, and multifunctional landscapes (Challies, 2008; Evans et al., 2002; Wilson, 2008). In 2005 both Friedmann and McMichael reinstated Food Regimes to the foreground of their work with separate and to some extent contrasting statements. Their emphasis is also different; greater attention is paid by both to regime transition and competing tensions within a Third Food Regime. ${ }^{1}$

This paper charts sociologists Friedmann and McMichael's engagements with Food Regimes thinking and its uptake by NZ geographers. The demise of Food Regimes as a conceptual framework in the mid to late 1990s is then examined. The 'elusive' Third Food Regime is then elaborated on. The meat industry in NZ serves as an empirical example for further interrogating this most recent reformulation of Food Regimes particularly as it relates to Friedmann's green consumerism and what

\footnotetext{
${ }^{1}$ A special issue of the Journal of Agriculture and Human Values (2009) 26(4) edited by Hugh Campbell and Jane Dixon published a set of papers about Food Regimes including further commentaries by both Friedmann and McMichael on Food Regimes analysis. This volume was not available at the time that the original conference presentation on which this paper is based was made. I have resisted the temptation to further rework it in the light of this more recent scrutiny of Food Regimes but would draw it to the attention of readers who may be interested in tracking further interest in food regimes on the part of agrifood researchers in a number of social sciences disciplines.
} 
McMichael $(2005,271)$ sees as the 'corporatization of agriculture and agro-exports'. This then sets the stage for a discussion of traceability, supply chain auditing, and the reorganization of supply chains as well as proposed mergers in the NZ meat industry consistent with Friedmann and Michael's reworked position on food regimes.

\section{The Rise and Demise of Food Regimes}

For geographers in NZ the entry point to Food Regimes was via Friedmann and McMichael (1989). Friedmann's earlier work had conceptualised family farming and the wheat market in the late $19^{\text {th }}$ and early $20^{\text {th }}$ centuries (Friedmann, 1978, 1978a). Separately McMichael $(1984,1987)$ had written on the agrarian question, class and state formation in colonial Australia. The 1989 paper on Food Regimes can be positioned as a continuation of their earlier individual research trajectories. Subsequently both Friedmann and McMichael separately wrote about the demise of the Second Food Regime and more speculatively about an emerging Third Food Regime (Friedmann, 1993, 1994, 1995; McMichael, 1992, 1993, 1994, 1996). Since then they have individually and jointly, revisited Food Regimes (Friedmann, 2005; McMichael 2005; McMichael and Friedmann, 2007).

The Food regimes concept was during the 1990s 'an attractive and widely used method for investigating the global politics of food' particularly as it related to understanding the interconnections between the development of nation states and the political economy of food (Pritchard, 2009, 221). Food regimes describe stable periods of food production trade and capital accumulation. Friedmann and McMichael identified a First Food Regime (circa 1870 to 1914) coinciding with the culmination of colonialism and settler agricultural exports coincident with the rise of metropolitan nation states followed by a transition period and a Second Food Regime from 1945 to circa 1973 in which there was a transnational restructuring of agriculture by agrifood corporates. This was followed by a further transition era that in which the stability of the Second Food Regime was eroded. A considerable amount of early work on food regimes was thus directed towards identifying conditions under which a Third Food Regime might emerge and of the anticipation of its characteristics (e.g. Le Heron and Roche, 1995). In the $21^{\text {st }}$ century Food Regimes have again 'garnered new-found credentials by way of providing a framework to explain global-scale reconfigurations of the world food order centred on private regulation of food trade (notably by transnational supermarkets) and the appropriation of green credentialing by these same actors' (Pritchard, 2009, 221).

Friedmann's work specifically mentioned Food Regimes as early as 1987 and still earlier prefigured them in the terms of 'International food orders' (Friedmann, 1982). In addition, she explicitly borrowed from political science on regime theory which had already incorporated the phrase Food Regimes (e.g. Bergesen, 1980; Puchala and Hopkins, 1978, 1982; Hopkins and Puchala, 1978). In developing Food Regimes as an historical concept Friedmann, however, moved it significantly away from its previous usage in the international organisation and political science literature.

Friedmann and McMichael (1989, 95) conceived of Food Regimes as linking 'international relations of food production and consumption to forms of accumulation broadly distinguishing periods of capitalist transformation since 1870' (they posited a First Food Regime from 1870 to 1914) followed by a transition phase and then the emergence of a second Food Regime from 1945 to 1973. Hopkins and Puchala, (1982) had, in different terms, written about a 1945-73 Food Regime/Food Order as well as illustrating their argument about international regimes with reference to a colonial regime (1870-1914). It seems reasonable to imagine that Friedmann and McMichael 
made an intuitive leap from this to point to sketch out a Food Regime that preceded the 1945-73 Regime and was anchored around the colonial empires and commodity exchanges of the late $19^{\text {th }}$ century. Friedmann (1982) had written about an International Pre war Food Order Food. In addition she had made detailed studies of the emergence of the wheat market while McMichael (1984) had written on various aspects of the agrarian question.

Goodman and Watts (1994) critically reviewed agrifood systems restructuring looking particularly at the regulationist literature. Although their main target was the uncritical extension of the language of industrial restructuring into the agricultural context, Food Regimes was also one of the casualties of their analysis. Goodman and Watts $(1994,20)$ highlighted what for them were 'a series of difficult questions' about the coherence of structure of the Food regime and the means by which the guiding rules are globally established. They questioned, 'In short to what extent is the concept vulnerable to the charge of hyper-structuralism, and not least of papering over any sense of agency?' (Goodman and Watts, 1994, 20).

McMichael (1996) responded to critics who he regarded as misunderstanding Food Regimes as 'a theoretical or an empirical construct' as follows:

'the concept of the food regime is a historical concept, which is why it addresses geopolitical rather than geographical concerns. As a historical concept, it is also comparative - not geographically but historically comparative. That is, it specifies the political history of capitalism understood from the perspective of food' (McMichael, 1996, 48).

He added, the 'concept is historical, and therefore not generalizable beyond the particular history being conceptualized. This kind of interpretative analysis is of a different epistemological order than that which seeks comprehensiveness or elegant (positivist) logical scenarios' (McMichael, 1996, 49). Further conceptual clarification between those on both sides of a Food Regimes debate was called for but not realized as 'regulation' and 'globalisation' captured and shaped the next phase of work of many of the participants.

\section{Antipodean Engagements with Food Regimes}

NZ geographers approached Food Regimes from two different directions. One group came from a background in theoretical and empirical work on family farming and off farm processing (Blunden et al. 1997, Moran et al. 1993, Moran et al. 1996). Others approached Food Regimes from a recently adopted political economy perspective (e.g. Cloke et al. 1990).

Drawing on research on family farms during a period of unprecedented Neoliberal reform, Moran et al. (1996) highlighted the accent on food rather than agriculture and the differences between the NZ and North American experiences. An important aspect of their criticism resided in what they regarded as the privileging of food over other agricultural-pastoral products. The consequence of this, they claimed, was that excessive attention was focused on agrifood corporates at the expense of other segments of the commodity production chain. Instead they sought to restore the family farm to centre stage, and made links to Friedmann's (1978, 1978a) work on family farms and simple commodity production to reinforce this point.

This critique perhaps revealed a deep desire to reify the place of family farms in the commodity production chain as the focus and scale of analysis. The other difficulty, as Moran et al. (1996) recognised, was that the category of 'family farming' made it 
difficult to clearly examine the timing of transformations in food regimes, the transition periods between regimes, and the uneven development of food regime geographies. More particularly they contended that Food Regimes was (1) of 'little value' in explaining individual national experiences, (2) the periodisation was 'necessarily hazy' (3) that French regulation school as the underpinning theory for their work did not provide a basis for explaining regime transition, and (4) that Food Regimes did not explain 'the differentiated experiences of farmers in nation states becoming integrated into world food systems. McMichael (1996), although not citing Moran et al. (1996), responded to these points.

The fullest expression of Food Regimes writing in the NZ was Globalized Agriculture, Political Choice (Le Heron, 1993) which laid out a globalisation model based on circuits of capital into which was folded a food regimes analysis. This included a schema for relating regimes of accumulation with the industrialisation of agriculture, techno-economic features and food regimes (Le Heron, 1993, 38). He suggested that Food Regimes provided a way to reconceptualise world food production and consumption, and that its richer promise lay in the fashion in which it might provide a 'framework for the exploring the regulatory issues of globalised agriculture' (Le Heron, 1993, 78).

Le Heron and Roche (1995, p. 24) subsequently argued that 'food regimes literature is surprisingly silent on geography' and that it's potential to 'inform contemporary debates about the historical geography of food and agriculture had so far been largely missed'. In attempting to address the first of these points they sketched out some attributes of a Third Food Regime as it appeared to be gaining form in the NZ context. This highlighted the intersection of globalization and sustainability, manifest particularly in 'fresh' foods. Roche (1999) subsequently addressed a second missing dimension; a detailed empirical study of first to second Food Regime transition in the context of the export frozen meat trades of Argentina, Australia and New Zealand. It pointed to the Ottawa Conference of 1932 marking the end of Empire free trade and the imposition of imperial preferences as a better point for the unraveling of the First Food Regime in the NZ setting.

\section{5: The Return of Food Regimes}

In 2005 both Friedmann and McMichael returned to Food Regimes. They reaffirmed their view of Food Regimes as historical categories and Friedmann continued with her relabeling of the earlier food regimes, now favouring 'ColonialDiasporic Food Regime' for the First Food Regime and 'Mercantile-Industrial Food Regime' for the second (Table 1). The 'Third Food regime' now captured their attention. Friedmann styled this the 'Corporate Environmental Food Regime' (CEFR). McMichael in contrast settled on a 'Corporate Food Regime' (CFR). Both authors also spent some time examining the transition between regimes, a point that had previously attracted the attention of their critics. Friedmann described the CEFR as 'a convergence of environmental politics and retail-led reorganization of food supply chains' consisting of 'two differentiated ways of organizing food supply chains, roughly corresponding to increasingly transnational classes of rich and poor consumers. Both are held by private capitals, some times the same firms selling quality and cheap commodities to different classes of consumers' (Friedmann, 2005, p. 251-252). McMichael (2005, p. 273) suggested 'the distinguishing mark of the corporate food regime as a new moment in world capitalism lies in the politics of neo-liberalism'.

Friedmann identified a new further round of accumulation in the agrifood sector, 'based on selective appropriation of demands by environmental movements, and 
including issues pressed by fair trade, consumer health, and animal welfare activists' (Friedmann, 2005, p. 229). While she regarded green politics as an important driver of change shaping an emergent CEFR, she is quite clear that it 'may serve only privileged consumers within a food regime rife with new contradictions' (Friedmann, 2005, p. 257).

Table 1: Evolution of food regime terminology in Friedmann and McMichael's Writing 1982 to 2005

\begin{tabular}{|c|c|c|c|c|c|c|c|}
\hline $\begin{array}{l}\text { Friedmann } \\
1982\end{array}$ & $\begin{array}{l}\text { Friedmann } \\
1987\end{array}$ & $\begin{array}{l}\text { Friedmann } \\
\& \\
\text { McMichael } \\
1989\end{array}$ & $\begin{array}{l}\text { McMichael } \\
1992\end{array}$ & $\begin{array}{l}\text { Friedmann } \\
1993\end{array}$ & $\begin{array}{l}\text { Friedmann } \\
1994\end{array}$ & $\begin{array}{l}\text { Friedmann } \\
2005\end{array}$ & $\begin{array}{l}\text { McMichael } \\
2005\end{array}$ \\
\hline $\begin{array}{l}\text { International } \\
\text { order } \\
\text { Pre war } \\
\text { Food order }\end{array}$ & $\begin{array}{l}\text { Extensive } \\
\text { first } \\
\text { international } \\
\text { food regime }\end{array}$ & $\begin{array}{l}\text { First Food } \\
\text { Regime }\end{array}$ & & & $\begin{array}{l}\text { Pre War } \\
\text { Food } \\
\text { Regime }\end{array}$ & $\begin{array}{l}\text { Colonial- } \\
\text { Diasporic } \\
\text { Food Regime }\end{array}$ & \\
\hline $\begin{array}{l}\text { International } \\
\text { food order } \\
\text { of the post } \\
\text { War period }\end{array}$ & $\begin{array}{l}\text { Second } \\
\text { international } \\
\text { food regime } \\
\text { (intensive or } \\
\text { Fordist } \\
\text { Regime \& } \\
\text { extensive) }\end{array}$ & $\begin{array}{l}\text { Second } \\
\text { Food } \\
\text { Regime }\end{array}$ & & $\begin{array}{l}\text { Surplus } \\
\text { Regime } \\
1947-72\end{array}$ & $\begin{array}{l}\text { Post War } \\
\text { Food } \\
\text { Regime }\end{array}$ & $\begin{array}{l}\text { Mercantile- } \\
\text { Industrial } \\
\text { Food Regime }\end{array}$ & \\
\hline A new order & $\begin{array}{l}\text { A new } \\
\text { international } \\
\text { regime }\end{array}$ & - & $\begin{array}{l}\text { Third Food } \\
\text { Regime }\end{array}$ & & & $\begin{array}{l}\text { Corporate- } \\
\text { Environmental } \\
\text { food regime }\end{array}$ & $\begin{array}{l}\text { Corporate } \\
\text { Food } \\
\text { Regime }\end{array}$ \\
\hline
\end{tabular}

Friedmann regarded 'food quality' as being of increasing importance. In her view it will however not be available to all, but importantly in conceptual terms for the CEFR, she argued that 'quality' commodities 'offered to privileged consumers are being constructed above the floor set by international organizations' (Friedmann, 2005, p. 253). This leads her on to a discussion of traceability, phytosanitary regulations, auditing of supply chains, certification and identity preservation. Belated recognition of the environmental dimension of a Third Food Regime also caused Friedmann (2005) to rework her original analysis to include the ecological impact of the Colonial-Diasporic Food Regime and the Mercantile-Industrial Food Regimes.

McMichael (2005, p. 271) meanwhile, in keeping with his interests in globalisation and Neo-Liberalism saw the CFR 'as a key vector of the global development'. It was characterized in his view by deregulation of financial services globally, credit (and debt), corporatization of agriculture and agro-exports, and the casualisation of labour. He, like Friedmann, continued to stress that the CFR was an historical category so that it emerged out of previous regimes. Nevertheless, he noted, it expressed 'a new moment in the political history of capital' (McMichael, 2005, p. 277). This was one accompanied by the 'decomposition' of sovereignty of states and of citizenship through a Neo-liberal 'globalization project.' One outcome had been 'an unprecedented conversion of agriculture across the world to the supply of a relatively affluent global consumer class' (McMichael, 2005, p. 277).

McMichael then traversed issues of food sovereignty and food security. He regarded the CFR as underpinning a tension between 'world' agriculture and [national] food sovereignty. For the moment concentrating just on food security and world agriculture, McMichael (2005, p. 295) argued that, 'The phenomenal dynamics of the 
corporate food regime, namely global dispossession of farmers, reorganization of food supply chains, and centralization of agri-food relations, express the immanence of capital and its a drives to deepen commodity relations'. In particular he pointed to the privatization of food security under a CFR.

Friedmann's discussion about quality food and related aspects of traceability, supply chain auditing and identity in conjunction with McMichael's insights about the corporatization of agriculture and agro-exports are used in this paper in order to look more sharply at corporate reorganization in the NZ export meat industry.

\section{The New Zealand Meat Industry in the $21^{\text {st }}$ Century and a Third Food Regime}

The 'durable foods' that characterised the Second Food Regime were exemplified by the international trade in frozen meat. The sector thus provides an important window in the New Zealand context into changes that might be wrought by the emergence of a Third Food Regime in that part of the world. The problems facing the NZ meat industry have been well rehearsed (Le Heron, 2002). The meat sector comprises processors of varying sizes, industry groups such as the Meat Industry Association, as well as statutory authorities such as the NZ Meat Board as well as farmer, union, and other governmental agencies. Since 2004 the NZ Meat Board's role in maximising returns to farmers has been limited to management of both export quotas, to provide some certainty for exporters to the EU and farmer financial reserves, partly for biotechnology development (NZ Meat Board, 2004). Exemplifying traditional attitudes (emblematic of the Second Food Regime), the Board opposed mandatory country of origin labelling in 2003 claiming it added 'unnecessarily costs, and wrongly implies that imported meat is of lower safety quality than domestic' (NZ Meat Board, 2004, 9). More proactively and consistent with Friedmann's CEFR, they developed a policy on animal identification and traceability in the aftermath of overseas reported cases of Bovine Spongiform Encephalopathy (BSE) to maintain NZ beef access in Japan. In 2007, 216 organisations were licensed to export meat from NZ (NZ Meat Board, 2007). Four NZ companies PPCS (Dunedin based), Alliance Group (Invercargill based), Affco (Auckland), and Anzco (Christchurch) with over $80 \%$ of the kill tally dominated the sector in 2007.

\section{PPCS: A Company Cameo}

PPCS, founded in 1948, was a 100\% farmer owned cooperative with 10000 farmer suppliers and 25 processing plants, with 9000 staff at peak, season across the country. These produced $32 \%$ and $31 \%$ respectively of NZ's sheep meat and beef exports in 2007 with an annual turn over of \$NZ2bill.

PPCS have sought to employ new technologies to secure better returns. This has involved three major initiatives in the areas of biotechnology, genetics, and electronics In 2001 PPCS took a 50\% share in Global Technologies (NZ) Ltd to investigate biotechnologies in order 'to enhance product quality' by 'improving traceability systems identifying genetic status and enhancing chilled meat standards', all of which were 'linked into the increasingly complex assurances sought by purchasers' (PPCS, 2001, 10). Tellingly the co-op also noted that competitiveness and growth could no longer be 'entrusted to third parties' (PPCS, 2001, p. 10). The ultimate goal was to process DNA samples in a commercially viable time frame in order to connect specific meat cuts back to the original carcass. By 2006 only 'steady progress' was reported (PPCS, 2006, p. 10). 
Other Technological developments included a robotic arm to bone out lamb cuts; four such devices being able to 'equal the throughput of a normal boning team' (PPCS, 2002, p. 8). The first trial arm was installed in 2003.

The third initiative related to Market Attributed Assessment Criteria (MAAC) whereby information on meat tenderness, fat and muscle distribution, weight and the like; indicators of desired taste and eating quality in the market were related back to specific stock on the farm. The automated technology for MAAC was installed on a trial basis at the Fairton plant in 2005 (PPCS, 2005, p. 8)

Investment in Global Technologies yielded immediate benefits for PPCS in terms of traceability of NZ meat and verification that it was free range and not GE. The firm commented on 'the importance of food safety and the ability to guarantee it, which now ranks ahead of price and quality in world markets' (PPCS, 2002, p. 9). Looking ahead they saw further value in traceability systems since 'confidence in meat products is constantly being eroded by animal health activists' (PPCS, 2002, p. 9)

\section{Technology is not enough}

By 2006 PPCS was more concerned about industry rationalisation. This occurred against a backdrop of significant conversion of sheep and beef country in Southland and Canterbury to dairy farms and a consequent fall in available stock numbers. By 2007 this had changed into a call to overcome industry fragmentation PPCS proposed 'a single entity embracing producers, processors and exporters that would provide a cohesive voice for industry at the political market-access level and be capable of effective co-ordinated action' (PPCS, 2007, 9).

Within the firm a new procurement model was launched (PPCS, 2007, 8). This had six guiding principles.

- A transparent pricing structure across the total supply base

- Supply to specification on grades and quality

- Volume supply premiums

- Season commitment to supply incentives

- Guaranteed processing space

- Direct PPCS- supplier procurement

These principles were intended to overcome the structural weakness of the industry where a 'carcass consignment' mentality had prevailed, where slaughtering was concentrated over a few months, where farmers would switch between competing processors for short term financial gain, and where stock and station agents functioned as an intermediate stock buyer between farmer and processor. In addition PPCS was able to reach 'forward supply agreements for lamb, beef and venison supplied to market specifications which give forward certainty on price' (PPCS, 2007, 8).

This new procurement system was intended to shift the processing away from a skewed seasonal killing tied seasons, to reward specific grades of sheep and offer a premium for quality. In turn PPSC signaled they would 're-configure plant throughput capacities to reflect limited volumes of livestock that will be processed under forward agreements' (PPCS, 2007a). Late in 2007 they announced new arrangements with UK chain Marks \& Spenser for supplying premium chilled lamb. They positioned the purchase agreements as 'the next logical step for PPCS' (PPCS, 2007). The supply agreement included not only weight and quality measures but guarantees about the genetics of the stock so that the desired taste and texture attributes would be reliably supplied. 
In 2008 PPCS announced a repositioning of the company away from its historic production-driven and cost reduction past to become 'marketing focussed' (PPCS, 2008). It was noted that with the NZ government then signaling the introduction of a carbon emission trading scheme, 'our international customers are increasing their requirements for accounting for the sustainability and environmental impact of our productions systems' (Cooper, 2008, PPCS, 2008). The 'food miles' issue was raised explicitly; 'some international markets are seeking to differentiate local and imported products on the basis of "food miles", despite scientific analysis concluding that the net energy inputs are lower for New Zealand meat exports than the local equivalents'. PPCS remained confident that, through high environmental standards, they could 'better meet the needs of our customers and the wider community while ensuring the long term viability of our business' (Cooper, 2008, PPCS, 2008).

A cornerstone of the new strategy was a bold decision to rebrand PPCS as Silver Fern Farms in an effort to 'take New Zealand product to the world and present a promise of purity, taste and quality' (Cooper, 2008, PPCS, 2008). Consistent with this approach PPCS supported the government's \$NZ13.2m National Animal Identification and Tracing Initiative (NAIT) arguing that it would safeguard NZ's reputation while observing that European markets were becoming impatient with the worldwide livestock industry which was perceived to be dragging its heels over identification and traceability,

'the premium is in ensuring ongoing market access, conforming to consumer trends and being proactive. It is appalling that Federated Farmers are not grasping that the supply chain must change, and that's about innovation and leadership' (PPCS, 2008b).

PPCS' 'right sizing' project also saw the closure of its processing plants at Burnside (Dunedin, 128 redundancies) and Oringi (near Dannevirke, 466 redundancies in a town of 5,600) (Hembry, 2008, Houlahan, 2008). PPCS justified its decisions on the grounds that stock numbers had declined by 500,000 lambs and 200000 ewes, which meant that the 10 export plants in the region has excess capacity, while national stock numbers were estimated to fall by 3 to 5 million from 2009-2012. CEO Cooper identified drought conditions, competition from other nearby slaughtering plants, dairy conversions and land moving from pastoral to arable use as part of the problem. He also claimed farmers were playing off one company against another for an extra two to three cents per kilogram and that this 'is probably half the problem we have in the industry today. Oringi reflects that mentality and we are changing our business model to encourage suppliers to commit to PPCS' (Morgan, 2008). The Labour coalition Minister of Agriculture roundly condemned the 'rightsizing' project - 'Ad hoc closures and rationalisations are not the best way forward for the meat industry, workers, and New Zealand as a whole' and argued instead for a industry wide strategic plan (Anderton, 2008).

In 2007 and 2008 there were further industry and state initiatives in the form of a so called 'mega merger' between the two leading co-operatives Alliance and PPCS, while a Meat Industry Task Force was set up by the government In June 2007 Alliance Group, the other major meat processing co-operative announce announced that it has engaged PricewaterhouseCoopers to undertaken appraisals of itself and PPCS with a view to exploring merger options (Alliance Group, 2007). The Alliance Group was established in 1948 and is also a cooperative, with 6,000 shareholders and 8 processing plants across the country. It produced $27 \%$ of NZ's sheep meat exports and $6 \%$ of beef exports employing over 5,000 at peak season with an annual turn over of $\$ 1.1$ bill. 
(Alliance Group, 2007). The Alliance plan sought to manage $80 \%$ of New Zealand livestock 'from farm to market' (PPCS, 2008a). Auckland based Affco affirmed that industry rationalization and marketing coordination was called for but argued that 'until there is tangible evidence that the South Island Cooperatives can find a way forward together and act jointly there is little point in AFFCO spending any further resources on the particular concept' (Affco, 2008). Industry commentators observed that with about $18 \%$ of the sheep meat market between them either Affco or Anzco would have to join the proposal to reach the $80 \%$ of livestock supply proposed in the Alliance megamerger scheme (Williams, 2008). Ultimately the Alliance megamerger foundered. The exact reasons are unclear; industry commentators suggested that PPCS debt levels were a concern to Alliance Group (Williams, 2008).

\section{A Different Merger: Silverfern Farms and PGG Wrightson}

By mid 2008 PPCS, now rebranded as Silver Fern Farms, announced a partnership proposal with stock and station firm PGGWrightson to 'improve returns to red meat farmers' and create a 'vertically integrated supply chain from "plate to pasture" focused on 'creating value by aligning farm production with market demand' (Silver Fern Farms PGGWrightson, 2008). The proposal was intended to overcome a 'crisis in the New Zealand red meat industry'. The objective was simply stated as enabling 'the livestock farming industry to maximize high-return opportunities from a growing worldwide market for the year-round supply of premium quality read meat products from animals specially bred and reared to meet specific consumer demand' (Silver Fern Farms PGGWrightson, 2008 n.p.). They noted 'the supply chain is not integrated, but is driven by grass growth'. To proceed, the partnership proposal needed the approval of $75 \%$ of Silver Fern co-op members. This was narrowly achieved but the global financial crisis thwarted efforts to raise the loans necessary for the merger to proceed.

Various actions of PPCS are consistent with McMichael's CFR, others with Friedmann's CEFR (Table 2). Both CFR and CEFR conditions lead to the reorganisation of food supply chains, but the table is useful for teasing out types of supply chain restructuring that are aligned more either to one or the other. This particular dissection of a New Zealand case, albeit of one the two largest processors, does not lend itself answering the question of whether researchers have to make a choice between the CEF and the CEFR. Even so it does suggest that apparent similarities between the two theorizations may be able to be differentiated empirically and this is a project deserving of future attention. Friedmann's CEFR is more sensitive to locally initiated change; Provisionally Table 2 suggests that there are more links between PPCS's trajectory and the CEFR than with the CEF. A caveat is that the quantity of connections may be less important than the strength of a few and New Zealand was the site of notable Neo-liberal experiments in the 1980s and 1990s. Even so, on balance in the New Zealand setting, at least with respect to the meat industry, its emerging characteristics of aThird Food Regime would seem to be more aligned to Friedmann's CEFR than McMichael's CFR. 
Table 2: Empirical Traces of Corporate Food Regime and Corporate Environmental Food Regime in the New Zealand Meat Industry 2000-2008

\begin{tabular}{|c|c|c|c|}
\hline $\begin{array}{l}\text { Corporate Food Regime } \\
\text { (McMichael) } \\
\text { Attributes }\end{array}$ & \multicolumn{2}{|c|}{$\begin{array}{l}\text { NZ meat industry examples } \\
\text { from PPCS and SFF }\end{array}$} & $\begin{array}{l}\text { Corporate Environmental Food } \\
\text { Regime } \\
\text { (Friedman) } \\
\text { Attributes }\end{array}$ \\
\hline Dispossession of farmers & $\begin{array}{l}\text { PPCS 'right } \\
\text { sizing project' } \\
2008 \\
\text { SFF 'pasture to } \\
\text { plate' } \\
\text { procurement } \\
\text { model commits } \\
\text { farmers to single } \\
\text { processor for the } \\
\text { year 2009 }\end{array}$ & 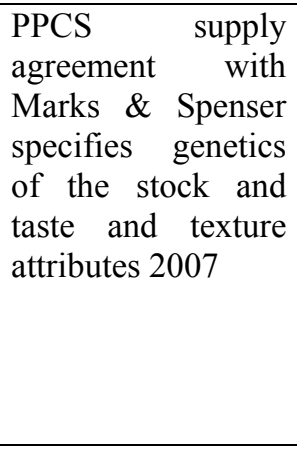 & Quality foods \\
\hline $\begin{array}{ll}---- \\
\end{array}$ & & $\begin{array}{l}\text { PPCS ree } \\
\text { improved meat } \\
\text { traceability as } \\
\text { means to alleviate } \\
\text { consumer food } \\
\text { safety concerns } \\
2001 \\
\text { 'Food miles' } \\
\text { recognised by } \\
\text { PPCS as a threat to } \\
\text { exports 2008 }\end{array}$ & Environmental movement \\
\hline $\begin{array}{l}\text { Reorganization of supply } \\
\text { chains }\end{array}$ & $\begin{array}{l}\text { PPCS uses } \\
\text { robotic arm to } \\
\text { bone lamb cuts } \\
2002 \\
\text { PPCS 'plate to } \\
\text { pasture " lamb } \\
\text { procurement } \\
\text { model 2007 } \\
\text { Proposed SFF } \\
\text { and PGG } \\
\begin{array}{l}\text { Wrightson } \\
\text { merger 2008 }\end{array}\end{array}$ & $\begin{array}{l}\text { PPCS collect data } \\
\text { on meat tenderness, } \\
\text { muscle distribution } \\
\text { as indicators of } \\
\text { desired taste and } \\
\text { eating qualities } \\
2005 \\
\text { Marks \& Spenser } \\
\text { PPCS UK supply } \\
\text { agreements } 2007\end{array}$ & $\begin{array}{l}\text { Retail led reorganization of } \\
\text { supply chains }\end{array}$ \\
\hline ------ & & $\begin{array}{l}\text { PPCS investment } \\
\text { in biotechnology to } \\
\text { improve } \\
\text { traceability of meat } \\
\text { through food } \\
\text { system } 2001\end{array}$ & Supply chain auditing food \\
\hline $\begin{array}{l}\text { Privatization of food } \\
\text { security }\end{array}$ & $\begin{array}{lr}\text { Failure } & \text { of NZ } \\
\text { Meat } & \text { Industry } \\
\text { Task } & \text { Force } \\
2007-8 & \end{array}$ & & \\
\hline
\end{tabular}

\section{Conclusion}

Food Regimes have been discussed as an historical concept with attention drawn to ways in which Friedmann and McMichael's have reworked their ideas about regime periodicity and the defining characteristics of specific regimes. Their more recent 
attention to regime transition will placate earlier critics. Likewise Friedmann's recognition of an environmental dimension of her Third Food Regime when read back against the First and Second Food Regimes aligns interestingly with NZ's environmental history (Brooking and Pawson, 2007).

The empirical example of the NZ export meat industry is pertinent in two ways; (1) Meat was an archetypal commodity of the Second Food Regime and (2) it is of interest to see how a NZ company such as PPCS attempted to move beyond industrial mass production of carcasses for export and engaged in a Third Food Regime sense with new technologies (some labour replacing) and traceability procedures in order gain a more secure foothold connection with European supermarkets. Traceability and food safety connect with Freidmann's CEFR, while other sectoral developments such as mergers and capital investment resonate with McMichael's CFR. In addition the example serves as a reminder that while Friedmann and McMichael may emphasis that Food Regimes are an historical category, their historical and contemporary geography remains under developed. The other comparison is with the NZ diary sector where Fonterra has become a major player in the international player (Stringer et al., 2007). Its success casts a shadow over the meat industry that has languished by comparison.

While the NZ meat industry example is informed by elements of Friedmann (2005) and McMichael (2005) of itself it does not privilege the CEFR or the CFR and further work on CFR and CEFR is required. In any case earlier skeptics will probably not be persuaded by Friedmann and McMichael's revival of the discussion about a Third Food Regime. But as the 'global food crises' of 2008 has been swept into the' global economic crisis' of 2009 it would be imprudent to too quickly discard their analysis.

\section{References}

Affco, (2008), 'News Alliance Merger Response', Media Release $29^{\text {th }}$ June.

Alliance Group, (2007), 'Meat Industry - Future Options Study', Media Release $28^{\text {th }}$ June.

Anderton, J. (2008), 'Oringi Meat Plant Closure'. $13^{\text {th }}$ May.

$<$ http://www.beehive.govt.nz/release/oringi+meat+plant+closure $>$ [downloaded 16-708].

Atkinson, H. (2008), 'Farmer ownership key to industry', Manawatu Evening Standard, $11^{\text {th }}$ July.

Blunden, G., Moran, W., and Bradly, A. (1997), 'Archaic' relations of production in modern agricultural systems: the example of New Zealand', Environment and Planning A, 29, 1759-1776.

Bergesen, H. O. (1980), 'A new food regime; necessary but impossible', International Organization, 34, 285-305.

Brooking, T. and Pawson, E., (2007), 'Silences of Grass: Retrieving the Role of Pasture Plants in the Development of New Zealand and the British Empire', The Journal of Imperial and Commonwealth History, 35, 417-435.

Challies, E .T. (2008), 'Commodity Chains, Rural Development and the Global Agrifood System', Geography Compass, 2, 375-394.

Cloke P., Le Heron, R., \& Roche, M. (1990),'Towards a political economy approach to understanding rural change: The example of New Zealand', Geografiska Annaler, 72B:13-25.

Evans, N., Morris, C., and Winter, M. (2002), 'Conceptualizing agriculture: a critique of post-productivism as the new orthodoxy', Progress in Human Geography, 26, 313-32. 
Friedmann, H. (1978) 'Simple commodity production and wage labour in the American plain'. Journal of Peasant Studies, 6, 71-100.

Friedmann, H. (1978a), 'World Market, State and Family Farm: Social Bases of Household Production in the era of Wage Labour',. Comparative Studies of Society and History, 20, 545-586.

Friedmann, H. (1982), 'The Political Economy of Food: the rise and fall of the postwar international food order', American Journal of Sociology, 88, S248-S286

Friedmann, H. (1987). 'The Family Farm and the International Food Regimes', in T. Shanin, (ed) Peasants \& Peasant Societies. Second edition (Oxford: Blackwell).

Friedmann, H. (1993), 'The Political Economy of Food: a Global Crisis', New Left Review, 197, 29-57.

Friedmann, H. (1994, 'Distance and Durability: Shaking Foundations of the World Food Economy', in P. McMichael, (ed) The Global Restructuring of Agro-Food Systems (Ithaca: Cornell University Press).

Friedmann, H. (1995), 'Food Politics: New Dangers, New Possibilities', in P. McMichael,(ed) Food and Agrarian Orders in the World Economy (Westport: Praeger).

Friedmann, H. (2005), 'From Colonialism to Green Capitalism: Social movements and the emergence of Food Regimes', in F. Buttel and P. McMichael, (eds) New Directions in the Sociology of Global Development (Amsterdam: Elsevier).

Friedmann, H. and McMichael P, (1989), 'Agriculture in the State System: the rise and fall of national agricultures 1870 to the present', Sociologia Ruralis, 29, 93-117.

Goodman, D. and Watts, M. (1994), 'Reconfiguring the Rural or Fording the Divide? Capitalist Restructuring and the Global Agro-Food Systems', Journal of Peasant Studies, 22, 1-49.

Hembry, O. (2008), 'Oringi closure sign of things to come in meat industry', $14^{\text {th }}$ May $<$ http://nzherald.co.nz $>$ [down loaded 11 July 2008]

Hopkins, R. and Puchala, D. (1978), 'Perspectives on the International Relations of Food', International Organization, 32, 581-616.

Houlahan, M. (2008), 'Plant's closure sign of tough times ahead for meat workers says union', New Zealand Herald, $14^{\text {th }}$ May.

Le Heron, R. (1992), 'Meat Freezing Industry Restructuring', in S. Britton, R. Le Heron, and E. Pawson, (eds) Changing Places in New Zealand, a geography of restructuring (Christchurch: New Zealand Geographical Society).

Le Heron, R. (1993), Globalised Agriculture (Oxford: Pergamon).

Le Heron, R. (2002), 'Globalisation, Food Regimes and "Rural" Networks', in I. Bowler, C. Bryant, and C. Cocklin, (eds) The sustainability of Rural Systems, Geographical Interpretations (Dordrecht: Kluwer).

Le Heron, R. and Roche, M. (1995), 'A Fresh Place for Food's Space', Area, 27, 23-33.

Lynch, B. (1996), 'Meat Industry Restructuring', in R. Le Heron, and E. Pawson, (eds) Changing Places New Zealand in the Nineties (Auckland: Longmans).

McKenna, M., Roche, M., and Le Heron, R., (1998), 'Sustaining the Fruits of Labour: A comparative Localities Analysis of the Integrated Fruit Production Programme in New Zealand's Apple Industry', Journal of Rural Studies, 14, 393-409.

McMichael, P. (1984). Settlers and the Agrarian Question, (New York: Cambridge University Press).

McMichael, P. (1987), 'Social change and the Relations between Capital and Landed Property', Australian \& New Zealand Journal of Sociology, 23, 423-432. 
McMichael, P. (1994), 'Global Restructuring: Some Lines of Inquiry', in P. Michael, (ed) The Global Restructuring of Agro-Food Systems (Ithaca: Cornell University Press).

McMichael, P. (1992), 'Tension between national and international control of the world food issue: contours of a new food regime', Sociological Perspectives, 43, 83105.

McMichael, P. (1993), 'World Food System restructuring under a GATT regime', Political Geography, 12, 198-214.

McMichael, P. (1996), 'Globalization: Myths and Realities', Rural Sociology, 61, 1555

McMichael, P. (2005), 'Global Development and the Corporate food Regime', in F. Buttel, and P. McMichael, (eds) New Directions in the Sociology of Global Development (Amsterdam: Elsevier).

McMichael, P. and Friedmann, H. (2007), "Situating the "Retailing Revolution", in G. Lawrence, and D. Burch, (eds) Supermarkets and Agri-food supply chains (Cheltenham: Edward Elgar).

Morgan, J. (2008), 'PPCS looks south after tough North Island cut', Dominion Post, $14^{\text {th }}$ May.

Moran, W., Blunden, G., and Greenwood, J. (1993, 'The role of family farming in agrarian change', Progress in Human Geography, 17, 22-42.

Moran, W., Blunden, G., Workman, M., and Bradly, A, (1996), 'Agro-commodity chains, family farms and food regimes', Journal of Rural Studies, 12, 245-258.

New Zealand Meat Board, Annual Report 2003-2004; 2006-2007.

Peren, R. (2006), Taste, Trade and Technology, the Development of the International Meat Industry since 1840 (Ashgate: Aldershot).

PGG Wrightson, (2008, The New Zealand Meat Industry: Creation of the Integrated Supply Chain. White Paper.

$<$ http://www.pggwrightson.co.nz/assests/--mis--/white\%paper.pdf $>\quad\left[\right.$ downloaded $9^{\text {th }}$ July 2008]

PPCS, Annual Report 2001, 2002, 2005, 2006, 2007.

PPCS, (2007), 'New Agreement connects PPCS Lamb Suppliers to UK Consumers', News Release, $11^{\text {th }}$ December.

PPCS, (2007a), 'PPCS Launches New Procurement Plan', News Release, $27^{\text {th }}$ April.

PPCS, (2008), 'Chief Executive Officer's Address AGM - Keith Cooper', News Release, $29^{\text {th }}$ February

PPCS, (2008a), 'Mega-Merger Viable- But the Current Structure is Flawed', News Release $18^{\text {th }}$ April

PPCS, (2008b), 'PPCS Backs traceability Scheme: Slams Federated Farmers', News Release $23^{\text {rd }}$ May

Pritchard, B. (2009) 'Food Regimes' in N. Thrift and R. Kitchin (eds) International encyclopedia of human geography, (Amsterdam: Elsevier).

Puchala, D. and Hopkins R. (1978), 'Toward Innovation in the Global Food Regime', International Organization, 32, 855-868.

Puchala, D. and Hopkins R (1982), 'International regimes: lessons from inductive analysis', International Organization, 36, 245-275.

Stringer, C., Tamásy, C., Le Heron R., and Gray, S. (2007), 'Growing a Global Resource-Based Company from New Zealand: The Case of Dairy Giant Fonterra', in C. Stringer, and R. Le Heron, (eds) Agri-commodity Chains and globalising Networks, Aldershot: Ashgate, pp.189-199. 
Williams, A. (2008), Anzco, Affco hold k<Http://nzfarmersweekly.co.nz $>$ [downloaded 29 June 2008]

Wilson, G. 2008, 'From 'weak' to 'strong' multifunctionality: conceptualising farm-level multifunctional transitional pathways', Journal of Rural Studies, 24, 367-383. 